\title{
Corporate Governance Implications For Earnings Quality
}

\author{
Sri Layla Wahyu Istanti, Agung Juliarto
}

\begin{abstract}
Earnings is an indicator of corporate performance evaluation. This study examines the role of leverage and corporate governance on earnings quality in banking companies in Indonesia. The results of the study indicate that higher leverage reduces the Earnings Quality. The high level of leverage indicates that the company has a large burden to pay off debt, so that it influences financial performance, especially profits. This model is consistent with previous empirical research. The age of firm, the proportion of commissioners' board and the number of audit committees as the implications of Corporate Governance have no significant effect on earnings quality. This research model is not consistent with the results of previous studies on the effect of corporate governance on Earnings Quality.
\end{abstract}

\section{Keywords: Earnings Quality, leverage, corporate governance.}

\section{INTRODUCTION}

Quantitative information in financial report reflects the company's financial position. The financial report is used by managers as a basis for corporate decision making. Earnings is one of the items from a financial report that can be used as an indicator of a company's financial performance measurement. One of the indicators to determine the company performance can be seen from the Earnings Quality. Stakeholders consider Earnings Quality as a tool for evaluating management performance.

In previous accounting research, there were various definitions of Earnings Quality in the perspective of usability in decision making The Earnings Quality leads to a reported profits' ability to reflect the actual condition of corporate profits to predict them in the upcoming period [1]. Cohen \& A (2010) states that current year's profits have good quality if they become good indicators for future profits, or they are strongly related to future operating cash flow [3].

Indonesia is a developing country with a very significant company's growth. The Indonesia Stock Exchange in the semester 1 of 2018 noted there was a significant profit's increase for the companies listed on the BEI. The increase was $21 \%$ in the first semester of 2108 or 178 trillion rupiahs compared to the company's profits listed on the BEI during the first semester of 2017 which was 147 trillion rupiahs. Government investment and household consumption are the main supporting factors for increasing Indonesia's economic growth.

The significant profit's increase indicates the increase of Earnings Quality. High quality profits are more trusted to

Sri Layla Wahyu Istanti, Economic of Doctoral Program, Diponegoro University, Semarang, Indonsia.

Agung Juliarto, Accounting Departement, Diponegoro University, Semarang, Indonsia.
Revised Manuscript Received on April 19, 2019.

provide accurate information about future profits predictions. For the reason, the Earnings Quality becomes a very interesting topic to study because it deals with the management of the company in managing companies and investors in evaluating management performance. Financial report as a reflection of the company's condition contains profits information that is very important for investors to assess the manager performance. The importance of profits information makes managers find various ways in preparing financial report in order to make it look effective and that there is a relationship between management and investor. However, their relationship in Earnings Quality often leads to agency conflicts. Jensen \& Meckling (1976) states that the agency conflict arises when there is a separation between the principal as the capital owner and the agent (manager) as the company manager.

The contribution of this study to the behavioral accounting literature and management accounting can broaden the scope of research on Earnings Quality in the context of consumer goods companies in Indonesia. Methodologically this research contributes to the previous literature relating to Earnings Quality by adding leverage variables and corporate governance implications. This research is expected to be a reference for stakeholders in looking at the quality of corporate profits with the its affecting factors. Some research on Earnings Quality have been done before, but the focus of this research is on some factors that influence the Earnings Quality based on the agency conflict from the perspective of leverage and the implications of Corporate Governance.

Leverage is a variable used to determine the number of company assets financed by debt, or company capital obtained from the debt [5]. The debt makes investors assume that the company will be more concerned with its payment than dividend payments [6]. The investor's assumption will affect the quality of obtained profits. The relationship between the investor's assumption related to the company assets financed by the debt has made the managers do their best to include the debt in their financial report.

The corporate governance is a set of rules that regulate the relationship between agents and principals related to their rights and obligations (Susanto dan Pradipta, 2016). Companies must obey the rules in corporate governance in order to create a transparent, accountable, independent and balanced company's condition by considering stakeholder positions. The regulations of the agents and principals' rights and obligations in corporate governance are expected 
to increase the value of the company reflected in the financial report, especially in the obtained profits. The company value increases if the resulted profit is getting more qualified. In this study, the corporate governance implications are company age, proportion of commissioners' board and audit committee.

The age of the company is the period of time it starts operating for unlimited time. The company's age reflects the company's ability to maintain its life, and it proves that the company is able to compete in an economic condition [8]. Its age is an implication of corporate governance, meaning that a long-established company is considered to have good credibility and is more stable than a newly established company, so investors can compare the performance of managers from year to year.

Sugianto \& Sjarief (2018) states that the Independent Board of Commissioners is a commissioner who has no financial, stock ownership or family relationship with other members of the commissioners board, so it does not affect the level of its independence. In the Corporate governance mechanism, the Board of Commissioners plays an important role because it is a neutral party between the agent and the principal. Its existence is expected to reduce the agency conflicts that occur in the company. Its proportion has been regulated by the Jakarta Stock Exchange on July 19, 2004, which is a minimum of $30 \%$ of all members of the board of commissioners.

Meanwhile, the audit committee is a committee within the company in charge of conducting the internal audits of the company. It is considered as a liaison between the shareholders and the commissioners' board and the management in handling control issues [10]. In corporate governance practices, it is expected to guarantee the company in carrying out its operations fairly and transparently. It is also responsible for supervising financial reports, overseeing external audits, and observing internal control systems. Its good performance within the company can reduce the agency conflicts.

The paper in this study is presented as follows: the first section consists of introduction; section two discusses literature review and hypothesis development. Section three describes the design of this study. The results of the study are discussed in section four and section five discusses the conclusions of this study.

\section{LITERATURE REVIEW}

\section{A. Agency Theory}

A separation between capital owners (investors) and company managers creates a conflict of interest between them. Agency theory first emerged with a modification of the conventional approach to accounting economic models by researchers, so as to reduce a little economic analysis and incorporate recognition of agency behavior. Jensen \& Meckling (1976) explains the agency theory makes a contractual model between two or more people (parties), which consists of agents and principals.

It is also known as contract theory, which assumes that companies have contracts with parties outside them. A work contract is a set of rules arranging the profit sharing mechanism, both in the form of benefits and risks approved by the principal and agent. An optimal work contract is a balanced contract between the principal and the agent that mathematically shows the implementation of optimal obligations by the agent and provides special rewards by the principal to the agent.

In agency theory, capital owners entrust the company's management to managers based on an approved contract. In implementing the work contracts, they tend to make efforts to fulfill the capital owners' will in order to improve their welfare. Principals as the capital owners rely solely on information obtained from managers related to paid dividends. The differences of interests between agents and principals can cause agency problems. One of the problems' causes is asymmetric information, that is, unbalanced information because of the unequal distribution of information between principals and agents. The conflict of interest will get worse if the principal does not directly monitor the performance of the manager.

\section{B.The Earnings Quality}

The company's main goal is to produce profits. Profit is an illustration of the company's financial performance that shows the manager's ability to realize its goals. Financial report is a means for managers to convey their performance that shows the company's condition. For the owners, a qualified capital report is indicated by high profit so the managers can act as the demands of the capital owners. When making and delivering financial report to the capital owners, the managers' action is based on their personal interests related to the level of their welfare.

The purpose of financial report is to provide information about the company's condition from a financial perspective so that it is useful to make some decision. For the reason, it needs to have some characteristics as qualified financial report.

Although the usefulness of financial information requires quality, the results of the study show that financial information or accounting information is not always of high quality. Schipper \& Vincent (2003) propose that Earnings Quality in particular and the quality of financial report in general are important for those who use financial report for the purpose of contract and investment decision making.

Earnings Quality is an indicator of income disclosure ability that can more accurately predict the future cash flows. Increasing profits indicates a qualified profit. The high Earnings Qualitys will make investors interested in increasing their investment in the hope of increasing higher dividend payments. Increasing the Earnings Quality shows that the investors are interested in information about profits (Molaei et.al, 2012).

Schipper \& Vincent (2003) classify the construct of Earnings Quality and its measurements based on the following characteristics:

First, based on the nature of profit-time period, Earnings Quality includes: persistence, predictability (predictive ability), and variability. On the basis of persistence, qualified profit is a persistent profit, i.e. a sustainable profit, 
more permanent and not transitory. Furthermore, predictive ability shows a profit capacity in predicting certain information items, for example future profits. In this case, high-quality profits are profits that have a high ability to predict future profits. Meanwhile, based on the construct of variability, high-quality profits are profits that have relatively low variability or smooth profits.

Second, Earnings Quality is based on profit-capitalaccrual relationship that can be measured by various measurements, those are: the ratio of operating cash to profits, changes in total accruals, abnormal estimates/discretionary accruals, and the estimation of cashaccrual relationship. Using a measure of the operating cash ratio to profit, Earnings Quality is indicated by the proximity of profit to operating cash flow. Profits getting closer to operating cash flow indicate the higher quality profits. Likewise, using a measure of total accrual changes, qualified profits are the profits that have a small total changes are caused by the in discretionary accruals changes. If the accruals are getting smaller, then the earnings quality gets higher. Earnings Quality can be measured using the relationship between accruals and cash flow. High earnings quality shows a close relationship between accruals and cash flows.

Third, quality earnings are profits that can be used as a basis for decision making. The measurement of each quality criterion separately is difficult, even not be done. Therefore, in empirical research, the price regression coefficient and stock return on profits (and other related measures such as cash flow) are interpreted as a measure of Earnings Quality based on relevance and reliability characteristics. Fourth, Earnings Quality is based on implementation decisions consisting of two approaches. In the first approach, earnings quality is negatively related to the number of considerations, estimates, and predictions needed by the financial report compiler. In the second approach, earnings quality is negatively related to the behavior of managers doing data manipulation (earnings management), meaning that the greater the earnings management, the lower the quality of earnings.

Earnings Quality can be defined as the profit ability to explain the information within it so that it can help the decision makers make decisions [13]. The importance of profit information causes managers to report the profits as much as possible to meet their personal interests. The managers' actions can lead to agency conflicts derived from the information about obtained profits. Cohen \& A (2010) state that current year's profits are of good quality if they become the indicators that can be used to predict future profits, or are strongly related to operating cash flows in the future.

\section{Leverage}

Leverage is a proxy used to measure the amount of assets financed by debt. The debt used to finance assets comes from creditors, not from shareholders or investors. Besides, agency theory is also used to explain the relationship between the company leverage and the disclosure of company annual reports. According to Jensen \& Meckling (1976), there is a potential to transfer the wealth from debt accrual change. This measurement assumes that total accrual

holders to shareholders and managers in the companies which have a very high level of debt dependence, so it arouses a very high agency cost.

Companies with a high proportion of debt in their capital structure will bear higher agency costs compared to the companies with a small proportion of debt. To reduce the cost agency, company management can reveal more increasing information along with the increasing level of leverage.

\section{Corporate Governance}

In agency theory there is a separation between the capital owner and the company manager. This separation can lead to agency conflicts arising from different interests. To overcome this conflict of interest, a mechanism is needed to able to control both of them so that the company can run to achieve its goals. Corporate governance is an effective mechanism that provides economic value so as to reduce agency conflict [14]. The implication of corporate governance, in this study, consists of company age, proportion of commissioners' board, and audit committee.

\section{E. Company age}

The age of the company shows the time the company has been used from its beginning (first established) to unlimited time. The company that has long been established is considered to have been able to survive and able to compete with other companies. By knowing its age, it will also be known to what extent it can survive. From the agency perspective, the age of the company is considered by investors as the manager's ability to manage it in a relatively long time. They tend to be more interested in investing in long-established company because they can compare the company's performance from time to time.

Proportion of Commissioners' Board The Independent Board of Commissioners is members of the commissioners' board who have no relationship with the company, creditors and company owners, to maintain their independence in the company. Agency theory bases itself on the relationship between shareholders and managers. The difference of interest causes asymmetric information (information gap) between the owner and company manager. The existence of an Independent Commissioner is important because in practice there are often transactions containing the conflicts of interest that ignore the interests of public shareholders (minority shareholders) and other stakeholders, especially in companies in Indonesia that use public funds in financing their businesses.

The board of commissioners plays an important role in the implementation of Good Corporate Governance (GCG) as the board of commissioners is the core of corporate governance whose duty is to ensure the implementation of the company's strategy, supervise the company's management, and oblige the company to implement the company's accountability. To ensure the implementation of Good Corporate Governance (GCG), the board members should have integrity, ability, illegally disabled and independent, and not have a business (contractual) or other 
relationship with a majority shareholder(controlling shareholder) and board of directors ( management) both directly and indirectly. Independent Commissioners are proposed and elected by minority shareholders who are not controlling shareholders in the GMS (General Meeting of Shareholders). The existence of commissioners' a board is a neutral party between agents and principals, and in charge of assisting to evaluate the company's financial position so that the profit information in the financial report is suitable with the actual conditions. Kuo, Wang, \& Lin (2015) state that through its role of supervisory function, the composition of the board can influence the management in preparing financial reports so that a qualified profit report can be obtained. The proportion of commissioners' the board is issued in the Jakarta Stock Exchange regulations. The existence of an independent commissioner is expected to reduce the agency conflict so as to create good corporate governance within the company.

\section{F. Audit Committee}

The existence of the Audit Committee is regulated through Circular Letter of Bapepam Number Kep29/PM/2004 (for public companies) and the Decree of Ministry of State-Owned Enterprises Number KEP103/MBU/2002 (for State-Owned Enterprises). The audit committee is a committee formed by the Board of Commissioners in order to help the commissioners carry out their duties and functions (Hashmi \& Brahmana, 2018).

The audit committee consists of at least one Independent outside the issuer or public company. In implementing its duties, the Audit Committee is in charge of assisting Commissioners Board to: 1) assess the implementation of activities and the results of audits conducted by the Internal Audit Unit and External Auditors the implementation and report that do not meet the standard can be prevented.; 2) provide some recommendations on improving the management control system of the company and its implementation, and 3) ensure that there are satisfactory review procedures for information issued by State-Owned Enterprises, including brochures, periodic reports, projections /forecasts and other financial information given to shareholders.

The audit committee has a very important and strategic role in terms of maintaining the credibility of the financial report preparation process as well as maintaining the creation of an adequate corporate supervision system and the implementation of good corporate governance. With the effective tasks of the audit committee, the control towards the company will be better, so that agency conflicts that occur due to management's desire to improve its own welfare can be minimized.

Hypothesis Development

Leverage and Earnings Quality company's assets financed by debt. The greater debt makes investors assume that the company will focus more on paying off the debt than paying dividend. The amount of debt also shows that the company's prospects are not good in the future. In the agency perspective, high levels of debt tend to make the managers manipulate the profits so that Commissioner and at least 2 (two) other members from

Leverage is a financial ratio that shows the size of a

they can cover the shortcomings that occur in the performance of financial report. Their behavior in managing profits will reduce Earnings Quality.

H1. There is a negative relationship between leverage and Earnings Quality.

Company age and Earnings Quality.Long-established companies generally have a more stable profitability than newly established companies. The manager's experience in making the company last in a long time shows that the manager has an ability to manage its finances. Thus, companies that do not produce profits will certainly not last longer.

$\mathrm{H} 2$. There is a positive relationship between company age and Earnings Quality.

The Proportion of Commissioners Board and Earnings Quality .The board of commissioners describes the top of a control system at the company. Its supervisory role is expected to minimize the agency conflicts arising between the board of directors and shareholders. The board of commissioners, as an independent institution, has the authority to evaluate the company's information from its financial report. The existence of commissioners' board is expected to reduce the agency problems. If they decrease, the management will be open in submitting reports, especially its financial report so that the Earnings Quality will also increase.

H3. There is a positive relationship between the proportion of commissioners' board and Earnings Quality

Audit Committee and Earnings Quality

The audit committee is responsible for supervising financial reports, overseeing external audits, and monitoring the internal control system. The existence of an audit committee is expected to reduce the opportunistic attitude of management that performs the profit management by monitoring the financial report and supervising the external audits [1]. It is also expected to reduce the profit management activities which, in turn, will affect Earnings Quality.

H4. There is a positive relationship between audit commitee and Earnings Quality.

\section{METHODOLOGY}

This study uses consumer goods companies listed on the Indonesia Stock Exchange with the total of 143 companies. The data source of this research is secondary data by taking the data from annual report of consumer goods companies in 2015-2017. The method of choosing the sample uses the purposive samples with a total sample of 42 companies.

\subsection{Research Variable}

\section{A. Earnings Quality}

In this study, dependent variable is Earnings Quality, which is a measure to match whether the profit obtained is the same as what was previously planned. Earnings Quality becomes higher if it approches the initial plan or exceeds the initial plan's target. Whereas It becomes low because profit presentation is not suitable with the actual profit so the 
information obtained from the profit report becomes biased, and as a result, its impact misleads creditors and investors in making decisions. [13]

The model used to calculate Earnings Quality is as follows:

Quality of Income = Operating Cash Flow

\section{EBIT}

\section{B. Leverage}

Leverage shows the proportion of debt usage to finance a company's investment. The higher the leverage number, the higher the company's dependence on the debt and the greater the risk, and consequently, the investors will ask for a higher level of profit. In this study, the equation used to calculate leverage is as follows:

Lev it $=\quad$ the total of company debt $i$ in the period of $\underline{t}$

the total of company asset $i$ in the period of $t$

C. Company Age

The company's age is the time from the beginning of the company operating until it can maintain its existence in the world of business (suvive). In this study, the age of the company is measured from the date of its operation until the end of 2017.

The Proportion of Commissioners Board An independent commissioner is a comparison of the number of independent commissioners owned by a company to the total number of members of the commissioners' board. The proportion of independent commissioners required by regulations issued by Bapepam Kep-05/PM/2002 on April 3 is a minimum of $25 \%$ of the total members or proportional to the number of minority shareholders (Laksono, 2011).

According to Muid (2009), the board of commissioners is determined by dividing the number of independent commissioners by the total number of commissioners in a company. In accordance with Muid's research, the proportion of independent commissioners is calculated by the formula:

The Proportion of Independent Commissioner = Independent commissioner The Total of Commissioners Board

\section{Audit Committee}

The audit committee is one of the committees formed by the board of commissioners and is responsible towards the commissioners' board. Its main duty and responsibility is to ensure the executives to apply the principles of good corpotare governance especially transparency and disclosure consistently and adequately (Tjager et.al, in Purwati, 2006). The measurement of the audit committee in this study uses the number of audit committee members in the company in the year of 2015-2017.

\section{E. Data Analysis Technique}

In this study, the data analysis technique uses Ordinary Last Square (OLS) regression. The use of regression analysis is to examine the effect of variable leverage (Lev), Company Age (Age), Proportion of Commissioners Board (Com) and Audit Committee (Aud.). The hypothesis testing, in this research, uses the following equation:

$\mathrm{EQ}=\mathrm{a}-\beta_{1} \mathrm{Lev}+\beta_{2}$ Age $+\beta_{3} \mathrm{Com}+\beta_{4}$ Aud $+\boldsymbol{\varepsilon}$

In this study, hypothesis testing uses a partial test. The testing criteria are carried out by comparing $t$ value statistics with critical points according to the table. If the $t$-statistic value of the calculation results is higher than the $t$-table value, the alternative hypothesis is accepted, in which an independent variable individually affects the dependent variable. The determination testing in this study is using the determination of adjusted $\mathrm{R}^{2}$. From testing together, the number of each affecting factors can be seen by looking at the coefficient of determination of adjusted $\mathrm{R}^{2}$.

\section{RESULT AND FINDING}

\section{A. Descriptive Analysis}

The results of descriptive statistics are explained in Table This study uses Earnings Quality as the dependent variable, and leverage and the implications of corporate governance as independent variables.

Tabel 1

Descriptive Statistics of Research Variabel

\begin{tabular}{llllll}
\hline Variable & $\mathbf{N}$ & Min & Max & Mean & Std. Deviation \\
\hline LEV & 42 & 0.178 & 0.612 & 0.37443 & 0.134469 \\
\hline AGE & 42 & 0.560 & 3.536 & 1.67557 & 0.776398 \\
\hline COM & 42 & 0.007 & 0.310 & 0.11000 & 0.075036 \\
\hline AUD & 42 & 0.43 & 2.484 & 0.58362 & 0.512969 \\
\hline EQ & 42 & 0.004 & 0.422 & 0.13119 & 0.097089 \\
\hline Valid N & 42 & & & & \\
(listwise) & & & & & \\
\hline
\end{tabular}

\section{Source: Secondary Data, processed in 2018}

From Table 1, it can be explained that from 42 observations, the independent variable of leverage (LEV) has a sample average value of $0.374 \%$ greater than the standard deviation value of $0.134 \%$. This result indicates that the observed company has leverage with a smaller variation than the average value. The minimum value of leverage (LEV) in the cosmetics and household needs subsector of Mandom Indonesia Tbk (TCID) in 2015 was $0.178 \%$, showing that there is company that has smaller leverage than the sample average value of $0.374 \%$ and has difference of $0.196 \%$. While the maximum value of leverage in the food and beverage sub-sector of Sekar Bumi Tbk (SKBM) in 2013 reaches $0.612 \%$ greater than the sample average value of $0.374 \%$ has a very large difference of up to $0.238 \%$. It indicates that the maximum value of leverage is greater than the sample average value.

The independent variable of Company Age (AGE) has a minimum value of $0.560 \%$, in which the cigarette sub-sector of Wismilak Inti Makmur Tbk (WIM) in 2014 has smaller value than the average sample value of $1.676 \%$ and has a considerable difference of $1.116 \%$. While the maximum value of AGE, that is the cosmetics and household subsector companies Martina Berto Tbk (MBTO) in 2013 is $3.536 \%$, greater than the average value of the sample of $1.676 \%$ so that the difference is quite large at $1.86 \%$. The average value of the AGE sample is $1.676 \%$ greater than the standard deviation value of $0.776 \%$, indicating that the observed AGE value of the company has a small variance

Published By: 
because the value of the standard deviation is smaller than the average value of the sample.

The independent variable, that is the proportion of commissioners board (KOM), has an average value of $0.110 \%$, which means that it is greater than the standard deviation value of $0.075 \%$. It indicates that the proportion of commissioner's board of the observed companies (KOM) has small variations because the standard deviation value is smaller than the average value. Likewise, the minimum value of the proportion of the commissioners' board (KOM) is $0.007 \%$, in which the cosmetic and household sub-sector companies Martina Berto Tbk (MBTO) in 2014 has smaller value than the average value of $0.110 \%$ with a difference of $0.103 \%$. While the maximum value of the proportion of the board of commissioners (KOM) is $0.310 \%$, in which the Delta Djakarta Tbk (DLTA) food and beverage sub-sector in the year of 2013 has greater value than the sample average value of 0.110 and there is a difference of $0.2 \%$.

The result of descriptive statistical test from the observations of 42 companies shows that the lowest (minimum) value of the independent variable, audit committee (AUD), was 0.043 trillion rupiahs, that is in the food and beverage sub-sector of Seka Bumi Tbk (SKBM) in the year of 2015 and the largest (maximum) value of AUD in the food and beverage sub-sector Tiga Pilar Sejahtera Food Tbk (AISA) in 2014 is 2.484 trillion rupiahs. The average value (mean) of AUD is 0.584 trillion rupiahs with a standard deviation of 5.513 trillion rupiahs. It shows that the audit committee (AUD) has a small variation because the standard deviation value is smaller than the sample average value (IDR 0.513 trillion < IDR 0.584 trillion) with a difference of IDR 0.071 trillion. While the smallest (minimum) value of AUD indicates that the observed company has a small audit committee value (AUD) compared to the average value of the sample (IDR 0.043 trillion < IDR 0.584 trillion) and has a difference of IDR 5.541 trillion. In addition, the maximum value of the audit committee (AUD) of IDR 2.484 trillion shows that it is greater than the average value of the sample of IDR 0.584 trillion and has a difference of IDR 1.9 trillion

Based on the results of the descriptive statistical test in Table 1 related to the dependent variable of the Earnings Qualitys (EQ) with the number of observations of 42 companies, it shows that the minimum EQ value in the Kedaung Indah Can Tbk household sub-sector in the year of 2014 is $0.004 \%$ meaning that the company has smaller EQ value than the sample's average value of $0.131 \%$ with a difference of $0.127 \%$. Meanwhile, the maximum value of EQ in the food and beverage sub-sector of Sekar Bumi Tbk (SKBM) in 2013 is $0.422 \%$, indicating that the difference between the EQ's maximum value is greater than the sample average value of $0.131 \%$ and has a difference of $0.291 \%$. The dependent variable of Earnings Quality (EQ) has a mean value of $0.131 \%$ greater than the standard deviation value of 0.097 , meaning that the observed company has Earnings Quality (EQ) with a small variation of the average value

\section{B. Regression Analysis}

This study uses regression analysis test with the purpose of determining the effect of leverage, company age, proportion of the Commissioners Board and audit committee on Earnings Quality. The regression test results can be seen in the following table:

Table 2

The Test Result of Multiple Linier Regression

\begin{tabular}{|c|c|c|c|c|c|c|}
\hline \multirow{2}{*}{ Model } & \multicolumn{2}{|c|}{$\begin{array}{l}\text { Unstandardized } \\
\text { Coefficient }\end{array}$} & \multirow{2}{*}{$\mathbf{T}$} & \multirow{2}{*}{ Sig. } & \multirow{2}{*}{$\begin{array}{l}\text { Hyp } \\
\text { othe } \\
\text { sis }\end{array}$} & \multirow{2}{*}{$\begin{array}{l}\text { Decisio } \\
\mathbf{n}\end{array}$} \\
\hline & B & $\begin{array}{l}\text { Std. } \\
\text { Error }\end{array}$ & & & & \\
\hline $\begin{array}{l}\text { (Consta } \\
\text { nt) }\end{array}$ & -0.183 & 0.084 & -2.180 & 0.36 & & \\
\hline LEV & 0.602 & 0.127 & 4.723 & 0.000 & $\mathrm{H} 1$ & Rejected \\
\hline AGE & 0.006 & 0.020 & 0.290 & 0.773 & $\mathrm{H} 2$ & Rejected \\
\hline $\mathrm{COM}$ & 0.542 & 0.176 & 3.074 & 0.04 & $\mathrm{H} 3$ & $\begin{array}{l}\text { Accepte } \\
\mathrm{d}\end{array}$ \\
\hline AUD & 0.034 & 0.023 & 1.507 & 0.140 & $\mathrm{H} 4$ & Rejected \\
\hline
\end{tabular}

Source: Secondary Data, processed in 2018

Based on the test results in Table 2 the equation of multiple linear regression models is systematically as follows:

$\mathrm{EQ}=-0,183+0,602 \mathrm{LEV}+0,006 \mathrm{AGE}+0,542 \mathrm{COM}$ $+0,034$ AUD + e

From the equation, it can be explained that the constant of -0.183 states that if the independent variables are considered constant, the average Earnings Quality (EQ) of consumer goods industry is -0.183 percent. The regression coefficient in Table 2 shows that if there is an increase in the leverage value of 1 percent, it will increase the Earnings Quality (EQ) of consumer goods industry by 0.602 percent.The results are that regression coefficient of company age (AGE) is 0.006 , the proportion of commissioners' board (COM) and audit committee (AUD) is 0.034 percent.

The first hypothesis states that leverage has a negative effect on Earnings Quality in consumer goods industry. In Table $1, \mathrm{t}_{\text {count }}$ LEV obtains 4.723 with a significant level of 0.000 . From the data, it can be concluded that the first hypothesis is rejected, because the research results state that leverage has a significant positive effect on Earnings Quality.

The second hypothesis states that company age has a positive effect on Earnings Quality in consumer goods industry. Table 2 shows that $\mathrm{t}_{\text {count }}$ AGE gets 0.290. From the data, it can be concluded that the second hypothesis is rejected, because the results of the study state that AGE does not affect Earnings Quality.

In Table 1, $\mathrm{t}_{\text {account }}$ COM obtains 3.074 so that the third hypothesis states that the proportion of commissioners board (COM) has a positive effect on Earnings Quality in consumer goods industry. From the data, it can be concluded that the third hypothesis is accepted because the results of the study state that COM has a positive effect on Earnings Quality.The fourth hypothesis states that audit committee has a positive effect on Earnings Quality in consumer goods 
industry. In Table 2, $\mathrm{t}_{\text {count }}$ AUD gets 0.034 , so it can be concluded that the fourth hypothesis is rejected because the study result states that AUD does not affect the Earnings Qualitys.

The estimation of regression results in the determination test can be seen in Table 3 .

\section{Tabel 3}

The Test Result of Determination

\begin{tabular}{|l|l|l|l|l|l|}
\hline $\begin{array}{l}\text { M } \\
\text { od } \\
\text { el }\end{array}$ & R & $\begin{array}{l}\text { R } \\
\text { Square }\end{array}$ & $\begin{array}{l}\text { Adjusted } \\
\text { R Square }\end{array}$ & $\begin{array}{l}\text { Std. Error } \\
\text { of the } \\
\text { Estimate }\end{array}$ & Durbin-Watson \\
\hline 1 & $\begin{array}{l}.70 \\
0^{\mathrm{a}}\end{array}$ & .490 & .434 & .073017 & 1.915 \\
\hline
\end{tabular}

a. Predictors: (Constant), LEV, AGE, COM, AUD

b. Dependent Variable: EQ

Source: Secondary Data, Processed in 2018

Based on the results of the determination test in Table 4, it is obtained nilai $R^{2}$ adjusted value of 0.434 in the consumer goods industry listed on the Indonesia Stock Exchange. This means that $43.4 \%$ of the dependent variable variation in Earnings Quality can be explained by variations in the independent variables of LEV, AGE, COM and AUD. While the rest of $56.6 \%(100 \%-43.4 \%=56.6 \%)$ is explained by the reasons for other factors outside the research model.

\section{CONCLUSION}

The effect of leverage (LEV) on Earnings Quality in the consumer goods industry listed on the Indonesia Stock Exchange

The hypothesis test result states that leverage (LEV) has a significant positive effect on Earnings Quality in the consumer goods industry listed on the Indonesia Stock Exchange. The research results indicate that leverage is very influential on the Earnings Quality. It means that the higher the leverage the higher the company's Earnings Quality.

The hypothesis test results are not suitable with the initial hypothesis which states that the leverage has a significant negative effect on Earnings Quality in the consumer goods industry listed on the Indonesia Stock Exchange. It shows that debt can be a substitute for the company's cash used as a source of investment finance. Companies can hold their cash in small amounts and use their funds obtained from their external sources (debt) for the company investment. Additionally, the principal wants the investment to be financed by the debt because there will be a control from the creditor to reduce the problem of overinvestment in the company. Thus, the relationship between the debt and the company's Earnings Quality is significantly positive. The results of this study indicate that though the company has a lot of debts, it is able to maintain its Earnings Quality. It is possible that investors do not expect too much on dividend payments because they have given the manager their trust in managing the company. In fact, the research results state that the leverage has a significant positive effect on investment policy.

The results of this study are not consistent with the research results of Wahyuni, et al. (2015), that is, the effect of managerial ownership, institutional ownership, financial leverage, and profitability on investment policies and its results show that the financial leverage has a significant negative effect on Earnings Quality. Furthermore, these results are also inconsistent with the research conducted by [17]), in which the effect of cash flow, investment opportunities, leverage, and working capital on Earnings Quality of fixed assets and the result is the leverage has no significant negative effect on Earnings Quality of fixed assets

The mechanism of corporate governance in this study shows various performances.

The company age in this study does not affect Earnings Quality. It means that the increase of company age does not affect Earnings Quality. Because the increase of its age is not a guarantee of the company's performance to be better, the market considers the existence of the company age is not a factor to take into consideration in appreciating Earnings Quality. It is because there has been an economic recession that has caused big companies to collapse in the last thirty years. Besides, large companies that have complex problems require a long time or slower movement to make changes so it is not flexible for them to respond to a recession.

According to agency theory, in relation to the age of the company, the shareholders and company management are expected to reduce agency cost. The research results contradict the research conducted by Godigbe, Chui, \& Liu, (2018) proving that that the age of the company has a significant positive effect on Earnings Quality.

The composition of the commissioners' board is one of the board's characteristics relating to the content of profits' information. Through its role in carrying out its supervisory function, the composition of the board can influence the management on preparing financial reports so that a qualified profit report can be obtained [9].

In this research, the third hypothesis predicts the composition of the commissioners' board has a positive effect on Earnings Quality. In hypothesis testing, the composition of the commissioners' board has a positive but insignificant effect on Earnings Quality. This research is supported by Godigbe et al., (2018) who found that the higher the proportion of independent commissioners, the higher Earnings Quality. This is because the independent commissioners will supervise the company so that the agency conflicts within it will increase.

The results of this study are not in line with the results of research conducted by Muid (2009) in which the composition of the commissioners' board, in this study, does not have a positive effect on Earnings Quality. This difference can be due to the selection of different samples and financial reporting years.The audit committee is responsible for supervising the financial reports, overseeing the external audits, and monitoring the internal control system. The existence of an audit committee is expected to reduce the opportunistic attitude of management that performs the profit management by monitoring the financial report and supervising the external audits [20].

The fourth hypothesis states that the audit committee is considered to have a positive effect on Earnings Quality. 
Based on the hypothesis testing, it can be concluded that the audit committee variable has a positive but an insignificant effect on the Earnings Quality. This research is in line with the results of a study conducted by Srivastava (2014) indicating that Earnings Quality is positively influenced by the audit committee.

However, the results of this study are not in accordance with Muid (2009) which found that the audit committees have a negative influence on Earnings Quality. This is probably due to the low level of corporate governance practices in companies in Indonesia. This difference can occur because of the sample differences and research years.

The limitations of this study include the data collected in which the data are only limited to the consumer goods company so that the samples obtained are relatively small. Another limitation is that data retrieval for three years has not been able to generalize the condition of consumer goods companies. The next limitation is that the independent variable consists only of leverage and corporate governance implications.

In spite of several limitations, this study provides a broad opportunity for further researchers to add to the samples by classifying the consumer goods companies with other companies and adding the years of research so that the data presented are more comparable among groups of companies.

\section{ACKNOWLEDGEMENT}

The research work is supported by STIE YPPI Rembang

\section{REFERENCES}

1. J. L. Gissel et al., "Earnings Quality: It' s Time to Measure and Report Earnings Quality: It' s Time to Measure and Report," vol. 75, no. 11, 2005.

2. D. A. Cohen and P. Z. Ã, "Accrual-based and real earnings management activities around seasoned equity offerings," J. Account. Econ., vol. 50, no. 1, pp. 2-19, 2010.

3. S. Cohen and O. Vlismas, "Analyzing the relations between intellectual capital and performance Sandra Cohen and Orestes Vlismas," pp. 1-33, 2011.

4. M. C. Jensen and W. H. Meckling, "Theory of the firm: Managerial behavior, agency costs and ownership structure," J. financ. econ., vol. 3, no. 4, pp. 305-360, 1976.

5. F. Hossain, "Impact of Firm Specific Factors on Capital Structure Decision: An Empirical Study of Bangladeshi Companies," Int. J. Bus. Res. Manag. (IJBRM, vol. 3, no. 4, pp. 163-182, 2012.

6. W. R. F. A. T. 3rd ed. T. . P. H. Scott, Financial Accounting Theory, 3rd ed. Toronto: Prentice Hall, 2003.

7. Y. K. Susanto and A. Pradipta, "Corporate governance and real earnings management," J. Int. Bisnis, Ekon. dan Huk., vol. 9, no. 1, pp. 17-23, 2016.

8. H. Thi, M. Khanh, and N. V. Khuong, "Audit Quality, Firm Characteristics and Real Earnings Management: The Case of Listed Vietnamese Firms," Int. J. Econ. Financ. Issues, vol. 8, no. 4, pp. 243-249, 2018.

9. S. Sugianto and J. Sjarief, "Analisis Pengaruh Kepemilikan Manajerial, Proporsi Dewan Komisaris Independen dan Konservatisme Akuntansi Terhadap Kualitas Laba serta Pengaruhnya terhadap Nilai Perusahaan," J. Akunt., vol. 12, no. 1, pp. 80-103, 2018.

10. Y. D. Pratiwi and W. Meiranto, "Pengaruh Penerapan Corporate Governance Terhadap Earnings Management
Melalui Manipulasi Aktivitas Riil," vol. 2, no. 1, pp. 115,2013

11. K. Schipper and L. Vincent, "Earnings Quality," in Accounting Horizon Suplement, 2003, pp. 97-110.

12. I. Molaei, D. Molaei, R. Yari, and M. Aghabaki, "The Investigation of Effecting factors on Earnings Quality," J. Basic Appl. Sci. Res., vol. 2, no. 3, pp. 3077-3080, 2012.

13. P. M. Dechow, "Understanding Earnings Quality: A Review of the Proxies, Their Determinants and Their Consequences Understanding Earnings Quality: A Review of the Proxies , Their," vol. 50, pp. 344-401, 2010.

14. B. K. Agyei-mensah, "Internal control information disclosure and corporate governance: evidence from an emerging market," Corp. Gov., vol. Vol. 16, no. 1, pp. 79-95, 2016.

15. H. Kuo, L. Wang, and D. Lin, "CEO Traits, Corporate Performance, and Financial Leverage," Int. J. Econ. Financ., vol. 7, no. 1, pp. 68-86, 2015.

16. M. A. Hashmi, R. K. Brahmana, E. Lau, and M. A. Hashmi, "Political connections, family fi rms and earnings quality," 2018.

17. C. C. Lee and C. K. Lin, "The major determinants of influencing the operating performance from the perspective of intellectual capital: Evidence on CPA industry," Asia Pacific Manag. Rev., 2018.

18. B. G. Godigbe, C. M. Chui, and C. Liu, "Directors network centrality and earnings quality," Appl. Econ., vol. 00, no. 00, pp. 1-20, 2018.

19. D. Muid, "Pengaruh Mekanisme Corporate Governance Terhadap Kualitas Laba," Fokus Ekon., vol. 4, no. 2, pp. 94-108, 2009.

20. L. H. Warrad, "The Influence of Leverage and Profitability on Earnings Quality: Jordanian Case," vol. 7, no. 10, pp. 62-81, 2017.

21. A. Srivastava, "Why have measures of earnings quality changed over time? \$," J. Account. Econ., vol. 57, no. 23, pp. 196-217, 2014.

\section{AUTHORS PROFILE}

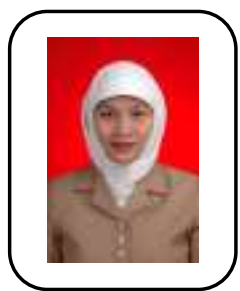

\section{First Author}

Sri Layla Wahyu Istanti is student in Economic And Bisnis Faculty on Diponegoro University, semarang, Indonesia. She is a reseacher and staff of education on STIE YPPI rembang, Indonesia. The focus of Research on Financial Accounting and Intellectual Capital on organization.

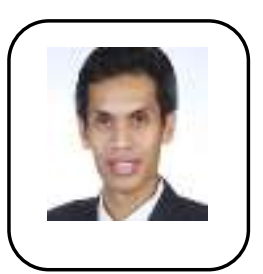

\section{Second Author}

Agung Juliarto is a Researcher and staff of education on Accounting Departement Economic and Bussines Faculty Diponegoro University, Semarang Indonesia. His focus of research on financial accounting. 